\title{
SLC7A8 wt Allele
}

National Cancer Institute

\section{Source}

National Cancer Institute. SLC7A8 wt Allele. NCI Thesaurus. Code C119002.

Human SLC7A8 wild-type allele is located in the vicinity of $14 q 11.2$ and is approximately $58 \mathrm{~kb}$ in length. This allele, which encodes large neutral amino acids transporter small subunit 2 protein, is involved in the transport of amino acids. 